\title{
The Impact of the 2014-16 Global Commodity Price Declines on Sub-Saharan African Financial Economy
}

\author{
Ashford C. Chea ${ }^{1}$ \\ ${ }^{1}$ School of Business and Economics, Benedict College, Columbia, USA \\ Correspondence: Ashford C. Chea, School of Business and Economics, Benedict College, 1340 Longcreek Drive \\ \# 508, Columbia, SC 29210 USA. Tel. 916-856-2197. E-mail: Ashfordchea@earthlink.net; \\ Ashford.chea@benedict.edu
}

Received: March 6, 2017

Accepted: April 18, 2017

Online Published: May 20, 2017

doi:10.5539/ijef.v9n6p162

URL: https://doi.org/10.5539/ijef.v9n6p162

\begin{abstract}
The aim of the article has been to ascertain the impact of the global commodity price declines on SSA's financial economy. Analysis showed that the global commodity price deterioration impacted SSA financial systems in many areas including increased borrowing costs, financial sector strains, and tighter private sector funding conditions. The article analyzes the traditional role of the financial sector in channeling capital to support the real economy in SSA. Also discussed are the linkages of the price shock on the continent's financial economy. Finally, the paper outlined the outlook and growth prospects for SSA financial sector stability and long-term development.
\end{abstract}

Keywords: commodity, price, declines, economy, financial, global, impact, Sub-Saharan Africa

\section{Introduction}

The recent 2014-16 global commodity price declines and financial markets volatility have affected several SSA financial sectors, although most economies were not impacted very much due to their isolation from the international capital markets (AfDB Statistics Department, 2013). But financial globalization has yet to recover. Good international lending environment led to an increase in bond issuance in many countries in SSA. However, lending requirements have been tightened, and cost of capital on the SSA's bonds have been increasing since 2014 (World Economic Outlook, April 2015). The paper's objectives are to ascertain: (1) the global commodity price declines and its impact on SSA's financial sector; (2) policy responses of SSA policy makers; (3) outlook for the SSA financial economy and potential risks; and (4) policy implications and recommendations for sustainable financial stability and development.

\section{Research Method}

This article is based on the analysis of relevant literature that centered around global commodity price declines and its impacts on SSA financial economy. The author screened articles by "global commodity price declines and SSA financial system", and by several keywords, concentrating on SSA financial environment (Chea, 2016). Sources used included peer-refereed research studies, and articles from relevant professional literature. As a result, all of the sources provided the data and information from which the findings and conclusions were drawn (Chea, 2015). The article starts with an analysis of the literature on the slowdown of global commodity prices and the transmission channels to SSA financial sectors.

\section{Analysis and Results}

Theoretically, financial development positively affects growth through several channels that are important for SSA. First, it helps to support efficient allocation of capital. Second, it supports diversification of risk. Third, it reduces information asymmetries and transaction costs (Regional Economic Outlook: SSA April, 2016). Global financial intermediation may also function as a link for the transmission of declining commodity prices to SSA financial economy (Husain et al., 2015). Moreover, the deterioration of financial flows as an outcome of unfavorable credit conditions in international monetary markets is a source of negative risks for the SSA. The key linkages of global financial risks transmission are through pressures on asset prices, cost of capital, and particularly exchange rates. These forces could negatively impact SSA financial economy. The key transmission implications are (1) higher costs of capital and refinancing for the public sector; (2) increased private sector 
financing environment; (3) renewed inflation uptick; and (4) financial system constrain (Regional Economic Outlook, April 2014).

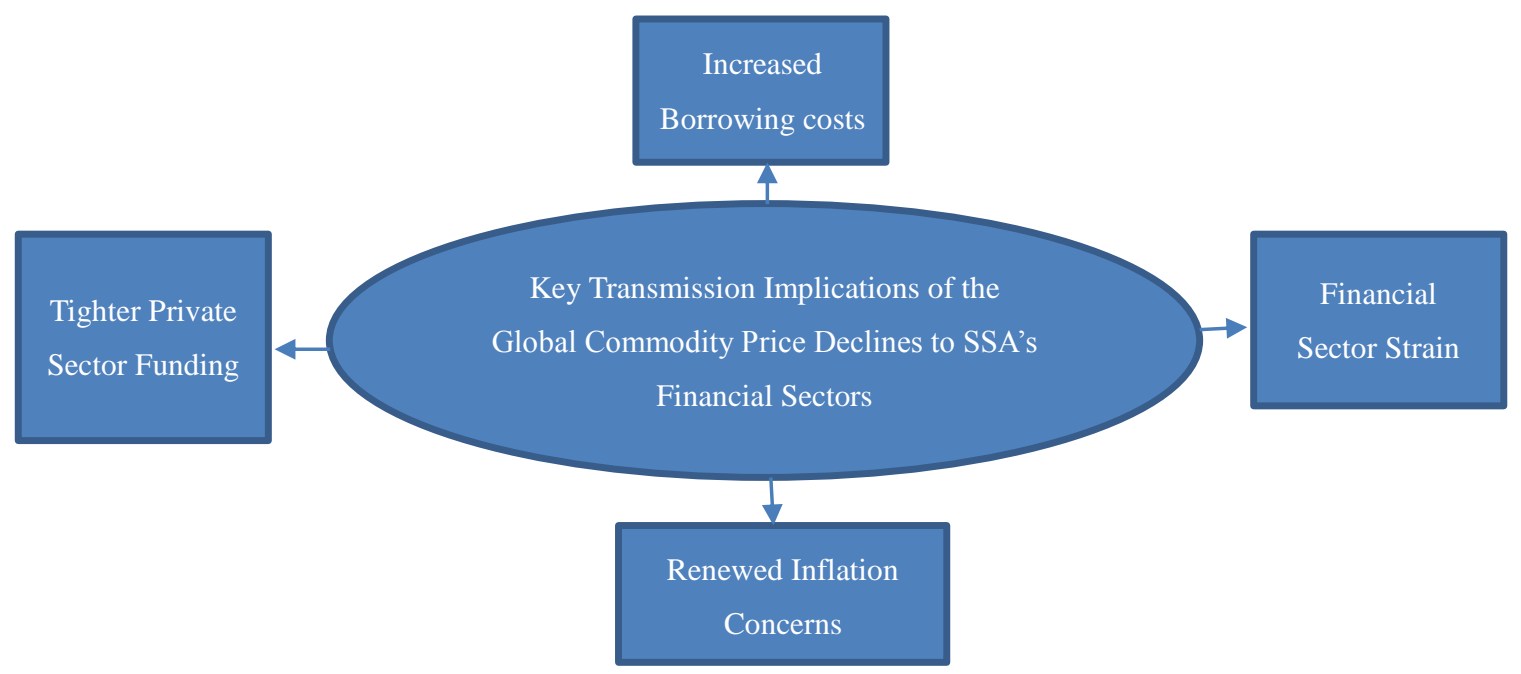

Figure 1. Key transmission implications

Note. Author's Construct.

Likewise, international commercial finance is a potential linkage between the financial systems and the real economy. For example, export credit facilities and bilateral lending from China have played a significant function as means for financing commerce and other economic development projects in SSA (African Development Bank, Statistics Dept., 2013). Research shows that private capital flows to SSA financial sector are neither evenly spread across nor diversified. However, with public sector bonds in developed economies offering low yields, western-country investment funds see SSA as a market for higher returns. And by raising capital in dollars, SSA economies could avoid the higher rates they pay to raise money in their local markets (The Economist, 2016).

Furthermore, SSA economies are also becoming increasingly integrated into the global capital markets for the first time. This helps SSA countries to diversify their financing sources away from development assistance. Integration into global financial markets has also brought more market discipline to government finances (Nwanma, May 2015). Because of this newfound access to global financial markets, economies in SSA are attracting large capital inflows into local credit and stock markets (Regional Economic Outlook, May 2013).

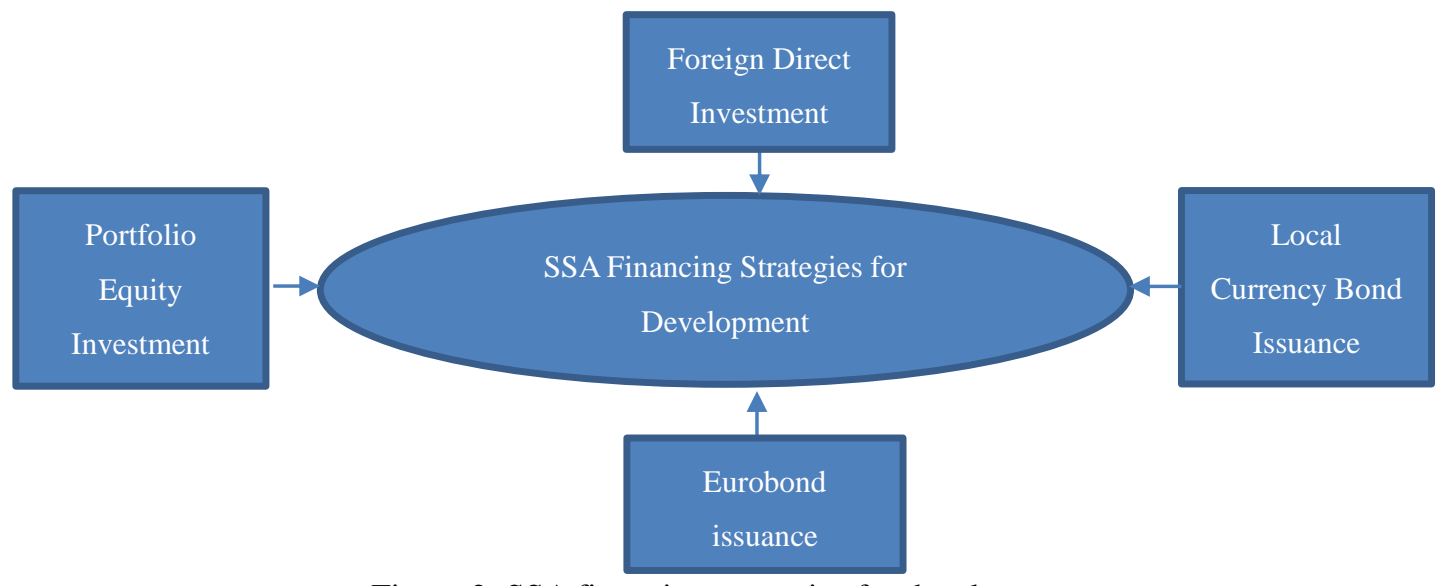

Figure 2. SSA financing strategies for development

Note. Author's Construct.

However, bruised by a significant increase in their debt, SSA seemed to heed IMF managing director Christine Lagarde's 2014 warning, eschewing Eurobond sales in 2015 and 2016 (Barghini, 2016). Also, many SSA countries are struggling with dwindling foreign reserves and weakened currencies (Nwanma, 2015). 
Table 1. SSA Debt: Countries with low debt and a solid policy framework (end 2015)

\begin{tabular}{lcc}
\hline Country Name & Yield to Maturity & Debt to GDP \\
\hline Cameroon & $7.79 \%$ & $33.5 \%$ \\
Ethiopia & 6.91 & 48.6 \\
Gabon & 7.69 & 43.9 \\
Ivory Coast & 5.31 & 34.7 \\
Namibia & 4.21 & 27.2 \\
Nigeria & 6.31 & 11.5 \\
Rwanda & 6.28 & 34.6 \\
\hline
\end{tabular}

Table 2. SSA Debt: Countries with high debt and weakening fundamentals (end 2015)

\begin{tabular}{lcc}
\hline Ghana & $9.58 \%$ & $73.3 \%$ \\
Kenya & 7.04 & 52.7 \\
Zambia & 9.10 & 53 \\
\hline
\end{tabular}

Table 3. SSA Debt: Countries with acute payment stress (end 2015)

\begin{tabular}{lcc}
\hline Angola & $9.55 \%$ & $62.3 \%$ \\
Congo & 9.97 & 65 \\
Mozambique & 16.91 & 75 \\
\hline
\end{tabular}

Source: Global Finance Magazine.

The recent decline in oil prices could trigger financial strains in many SSA countries. Three potential sources of financial vulnerabilities are (1) increasing credit risk; (2) deteriorating financing environment for the commodity sector; (3) a decline in global financial surplus from the commodity sector; and (4) constrains in the capacity of the international financial market to deal with a lengthened period of increased commodity price stability (Husain et al., 2015).

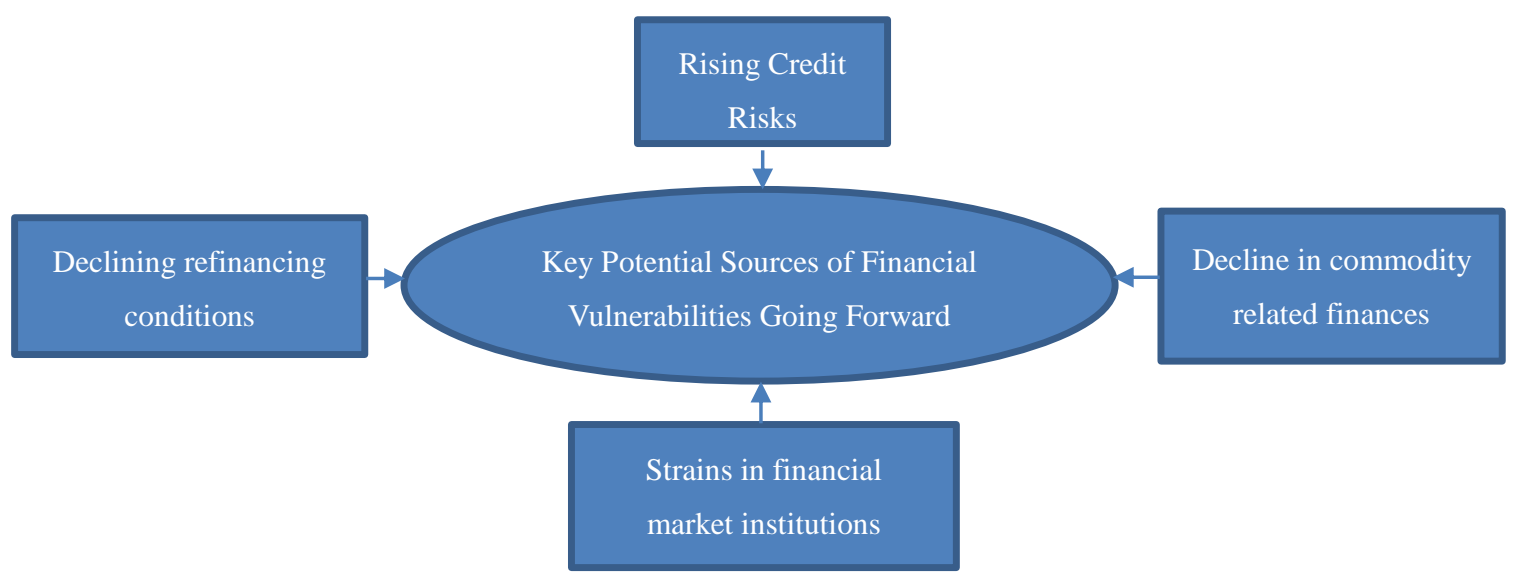

Figure 3. Sources of financial vulnerabilities

Note. Author's Construct.

Additionally, bank lending in global currencies could result into a rise in bad loans if large currency declines have a negative impact on their borrowers' repayment ability. Global banks could also incur losses in local stock, bond and real asset investments (Regional Economic Outlook April 2014). For instance, these risks increase the potential for financial system shocks to be transmitted across SSA (Regional Economic Outlook: Sub-Saharan Africa, October 2012).Finally, as a result of declining surpluses in their current accounts and reserves position, the amount of export credits, resource-backed credit lines and alternative financing facilities extended to SSA by China could be reduced significantly (African Economic Outlook, 2016).

\section{Findings}

This research has found that financial stability metrics in commodity- rich economies, such as bank profitability 
or bad loans, tend to decline and the chances of systemic financial sector crises tends to heighten in the event of declining commodity price shocks. Such negative spillover to the financial system are likely to affect credit supply to SSA economies (Regional Economic Outlook, October 2015). Similarly should material exchange rate deterioration or a sudden increase in global costs of capital materialize, it could have implications for medium and long-term financial stability and development in the region. First, SSA commercial banks' international debts are relatively small and net foreign asset positions is at 2.1 percent of GDP on average. However, gross international debts have surged significantly and there is a high disproportionate share of loans to the energy sector (Regional Economic Outlook, April 2015).

Moreover, low-income SSA economies need to strengthen all areas of domestic credit and stock market development and create the right currency borrowing (and creditor) combination (Ahmed, 2008). This would enable the financial system to efficiently channel surplus savings into profitable investments to support economic growth (Thakoor \& Wakeman-Linn, 2016). Likewise, countries in SSA can deal with an unfavorable international financial environments by preserving their fiscal and financial flexibility. Dealing with capital reversals would require putting in place an integrated policy framework -including monetary, fiscal, structural, and exchange rate (Regional Economic Outlook, April 2014). Additionally, some policy actions to pursue include undertaking productivity-enhancing infrastructure investment and human capital development (Regional Economic Outlook, October 2015).

\section{Conclusions}

The 2014-16 global commodity price declines and its associated ongoing foreign currency crisis in parts of the continent has slowed down the pace of SSA's integration with global financial markets (Nwanma, 2015). However, the newfound capacity of SSA economies to access international capital at reasonable cost provides a potentially significant new stream of development funding for these economies. Creating the infrastructure to effectively plan and execute the bond-issuance process and ensuing sustainable debt management is essential (Regional Economic Outlook, May 2013). Also critical to successful financial sector stability and development in SSA is the strengthening of supervision. In sum, financial sectors in most SSA economies are underdeveloped and illiquid. They lack depth and breath. Financial deepening and integration could help use the increased surplus savings to finance profitable investments and ventures (Regional Economic Outlook: Sub-Saharan Africa, October, 2006). At the same time, countries in SSA are accessing global financial markets. While such financing is key for SSA countries, the concern is that these financial inflows may have become a regular source of financing for economic growth and development (Regional Economic Outlook, April 2015).

\section{References}

African Development Bank. (2013). Africa and global economic trends. Quarterly Statistical Review, 16, 1-15.

African Economic Outlook. (2016). Africa's macroeconomic prospects. African Development Bank, Abidjan.

Barghini, T. (2016). African debt loads to grow again. Global Finance, April, 97.

Chea, A. (2015). The euro zone economic crisis and sub-Saharan Africa's real economy: Analysis and the way forward. Business and Economic Research, 5(2), 256-268. https://doi.org/10.5296/ber.v5i2.8594

Chea, A. (2016). The euro zone financial meltdown and sub-Saharan Africa's financial sector: Analysis and the way forward for financial development and economic growth. International Journal of Regional Development, 3(1), 81-91. https://doi.org/10.5296/ijrd.v3i1.8925

Husain, A. M., Arezki, R., Breuer, P. et al. (2015). Global implications of lower oil prices. IMF Staff Discussion Note, International Monetary Fund, Washington, D. C. https://doi.org/10.5089/9781513532417.006

Nwanma, V. (2015a). The African growth story grinds to a halt. Global Finance, December, 28-29.

Nwanma, V. (2015b). Sub-Saharan Africa outpaces bigger competitors. Global Finance, May, 26-28.

Regional Economic Outlook. (2012). Sub-Saharan Africa: Maintaining growth in an uncertain world. International Monetary Fund, Washington, D.C., October.

Regional Economic Outlook. (2013). Sub-Saharan Africa: Building momentum in a multi-speed world. International Monetary Fund, Washington, D. C., May.

Regional Economic Outlook. (2014). Sub-Saharan Africa: Fostering durable and inclusive growth. International Monetary Fund, Washington, D.C., April.

Regional Economic Outlook. (2015a). Sub-Saharan Africa: Dealing with the gathering clouds. International Monetary Fund, Washington, D. C., October. 
Regional Economic Outlook. (2015b). Sub-Saharan Africa: Navigating headwinds. International Monetary Fund, Washington, D.C., April.

Regional Economic Outlook. (2016). Sub-Saharan Africa: Time for a policy reset. International Monetary Fund, Washington, D.C., April.

Thakoor, V., \& Wakerman-Linn, J. (2016). Surf the demographic wave: Sub-Saharan Africa could reap significant benefits from the growing population - if the transition is well managed. Finance \& Development, 53(1).

The Economist. (2016). Ante upped: Africa discovers the downside of foreign borrowing. The Economist, April, 72-73.

World Economic Outlook. (2013). Uneven growth: Short and long-term factors. IMF, Washington, DC. April.

\section{Copyrights}

Copyright for this article is retained by the author(s), with first publication rights granted to the journal.

This is an open-access article distributed under the terms and conditions of the Creative Commons Attribution license (http://creativecommons.org/licenses/by/4.0/). 